\title{
Stem exclusion and mortality in unmanaged subalpine forests of the Swiss Alps
}

\author{
Frank Krumm • Dominik Kulakowski • \\ Anita C. Risch · Heinrich Spiecker • \\ Urs-Beat Brändli • Peter Bebi
}

Received: 25 July 2011/Revised: 17 December 2011/Accepted: 16 March 2012/Published online: 3 April 2012

(C) Springer-Verlag 2012

\begin{abstract}
Understanding the causes and consequences of spatiotemporal structural development in forest ecosystems is an important goal of basic and applied ecological research. Most existing knowledge about the sequence and timing of distinct structural stages following stand origin in unmanaged (not actively managed in $>50$ years) forests has been derived from forests in North America, which are characterized by particular topographic, climatic, biotic and other environmental factors. Thus, the effects on structural development remain poorly understood for many other forest systems, such as the dense, unmanaged, subalpine Norway spruce forests of the Swiss Alps. Over the past century, land abandonment and reductions in active forest management have led to a substantial increase in the
\end{abstract}

Communicated by C. Ammer.

F. Krumm $(\bowtie) \cdot$ P. Bebi

WSL Institute for Snow and Avalanche Research SLF,

Flüelastrasse 11, 7260 Davos Dorf, Switzerland

e-mail: krumm@slf.ch

P. Bebi

e-mail: bebi@slf.ch

D. Kulakowski

School of Geography, Clark University, Worcester, MA, USA

e-mail:dkulakowski@clarku.edu

A. C. Risch · U.-B. Brändli

Swiss Federal Institute of Forest, Snow and Landscape Research,

8903 Birmensdorf, Switzerland

e-mail: anita.risch@wsl.ch

U.-B. Brändli

e-mail: urs-beat.braendli@wsl.ch

H. Spiecker

Institute for Forest Growth IWW, Freiburg, Germany

e-mail: instww@iww.uni-freiburg.de density of these forests types. Consequently, many stands are entering the stem exclusion stage and are currently characterized by associated self-thinning mortality. However, the environmental influences on the rate of this structural development as well as this structural stage itself have not yet been examined. We studied stem exclusion processes based on forest inventory data (National Swiss Forest Inventory; NFI) over three survey periods (1983-1985, 1993-1995 and 2004-2006) using repeated measures statistics. To complement these analyses, we also collected and analysed 3,700 increment cores from 20 field plots within dense subalpine Norway spruce forests dispersed across the Swiss Alps. Over the past decades, basal area (BA) has generally increased, particularly on $\mathrm{N}$-facing and steeper slopes, and within $300 \mathrm{~m}$ of potential treeline. The number of dead trees was higher on $\mathrm{N}$-facing compared with S-facing slopes, but the BA of dead wood was higher on S-facing slopes. Tree ring analysis confirmed important differences in growth patterns between $\mathrm{N}$ - and $\mathrm{S}$-facing slopes and verified the results of the NFI analysis. This study provides a detailed example of how environmental heterogeneity and management history can influence the spatiotemporal structural development of forest ecosystems.

Keywords Forest development - Self-thinning · Norway spruce $\cdot$ Dendroecology $\cdot$ National Forest Inventory (NFI) $\cdot$ Competition

\section{Introduction}

Current ecological theory recognizes change as an inherent characteristic of all ecosystems. Identifying the factors that drive spatial and temporal dynamics is an important goal of 
ecological research. A common conceptual model is used to describe structural stages in forest development and consists of four sequential stages (Oliver and Larson 1996; Barbour and Billings 1988; Peet 2000; Oliver 1980): (1) "Establishment": initial regeneration, often initiated by large-scale disturbances; (2) "stem exclusion" (also called "self-thinning"): intensive competition and exclusion of establishment of young trees due to absolute increasing tree density; (3) "Understory reinitiation": small- or large-scale breakdown, establishment of regeneration possible; (4) "Old-growth": when the overstory gradually dies and the understory slowly fills into replace it.

During the stem exclusion phase, trees are competing for light, water and soil nutrients (Oliver and Larson 1996). As a consequence, plants with competitive disadvantages reduce their growth or die (Das et al. 2011; McCarthy and Weetman 2006; Oliver and Larson 1996; Peet and Christensen 1987). The majority of subalpine forest stands in the Swiss Alps, which are dominated by Norway spruce (Picea abies), are currently characterized by constant or decreasing tree density (number of stems per unit area), while basal area (BA) and the volume of dead wood increase (Krumm et al. 2011; Brändli 2010). Such changes in forest structure are a typical precursor of advanced self-thinning (Spies et al. 1988; Peet and Christensen 1987).

The structural stage of European mountain forests is important for numerous reasons, including the protective function that these forests serve against avalanches, rockfall and other natural hazards. Protection function against natural hazards generally depend on forest structure, especially vertical structure, the number and dimensions of trees and on the size of gaps (Frehner et al. 2005; Brang 2004). Foresters generally aim to minimize large areas of selfthinning stands in protection forests, because of a scarcity of advanced regeneration, which can reduce the resilience (Grimm and Wissel 1997). In the context of other forest values, self-thinning causes natural mortality and influences indirectly wildlife habitat and biodiversity (Holeksa 2001; Stevens 1997) by providing habitats and nutrients.

Current forest structure in the Swiss Alps is largely a legacy of land abandonment such as reduced grazing activities as well as use of fuel and construction wood (Gehrig-Fasel 2007; Gellrich et al. 2007; Körner 2003) over the last 100-150 years. Many forests in this region have not been managed since the time of land abandonment (5-10 decades ago) because of poor accessibility and high management/harvesting costs. As a consequence, they have reached a stage of stem exclusion, which is often characterized by intensive endogenous competition for resources (Antos and Parish 2002; Chen and Popadiouk 2002; Cumming et al. 2000).

In forest ecosystems, the rate of change is dependent on environmental factors including temperature and precipitation, topographical setting (aspect, elevation, steepness) and microtopographic features (gullies, ridges) which all influence the duration of snow cover, soil temperature, wind and biogeochemical conditions (Schönenberger 2001; Ott et al. 1997; Aulitzky 1984). Forest structural changes and the duration of different stand development phases can therefore considerably vary with site conditions. For example, in some high-elevation subalpine forests, where resources are scarce and forest density is lower compared with low-elevation sites, stem exclusion stages may be bypassed (Peet 2000). In areas where stem exclusion does occur, it is generally unknown how long it takes for this phase to be initiated if forests are unmanaged. Similarly, not much is known about how different topographic factors such as elevation, aspect and steepness may influence the speed of these processes.

In general, BA and stem density are greater on south than N-facing slopes in subalpine forests of the Swiss Alps (Krumm et al. 2011), suggesting that lower temperatures are limiting to tree establishment and growth. However, historically S-facing slopes were preferred for grazing, which led these areas being abandoned later than $\mathrm{N}$-facing slopes (Ott 1978). Thus, also these historical management differences are likely to contribute to the pronounced differences in stem density and BA on north- versus southfacing slopes.

Suppressed trees can often tolerate high stress in dense forest stands. They can adapt to low resources by growing slowly and thus contribute to the vertical heterogeneity of the stand, which in turn can increase stand resilience (Antos et al. 2005). However, this ability varies across stands with different tree composition, and it is not clear how long $P$. abies are able to survive in the understory of subalpine forests. P. abies can tolerate low light intensities, but regeneration success increases drastically with increased light levels (Leemans 1991). The shade tolerance of trees is normally highest when trees are small and then decreases as trees grow larger (Lyr et al. 1992). A better understanding of competition derived mortality as a critical part of the natural dynamics of forest ecosystems is important and would facilitate predictions of future trends across different environmental conditions (Loehle and LeBlanc 1996; Harmon et al. 1986). Competition can contribute to continuous mortality (Peet and Christensen 1987), as growth and vigour of suppressed trees decrease prior to mortality (Bigler 2003). Studies on self-thinning in planted and managed European forests conducted at lower elevations reported mortality processes to be "U" shaped with high mortality in early stages of cohort growth, a slow phase when trees are established followed by high mortality due to senescence (Platter and Sterba 2008; Monserud and Sterba 1999). However, processes that create dead wood as well as their rates in response to competition and 
stem exclusion in high-elevation regions remain poorly understood and do likely vary in space and time depending on topographic setting (Bigler 2003; Szwagrzyk and Szewczyk 2001; Villalba and Veblen 1998).

We address the following questions for the unmanaged, subalpine spruce forests in the Swiss Alps: (1) How widespread are stands in the stem exclusion phase in the Swiss Alps? We hypothesize that stem exclusion is extensive and that this forest stage is not bypassed in the European Alps as might be the case in other subalpine environments (Peet and Christensen 1987). Furthermore, the increase in stem density will culminate in the near future and mortality rates will increase significantly due to self-thinning processes. (2) How do topographical factors such as distance to treeline, aspect and steepness affect stem exclusion processes in subalpine forests? We hypothesize increasing BA with further distances to treeline, on southern exposures and on slopes that are $<30^{\circ}$ steep. (3) When does competition within a stand begin (years after establishment) and how does this vary with topographic setting? It is expected that intra-specific competition starts when the canopy is closed and lasts approximately 50 years. We also expect smallerscale stem exclusion and time delay depending on distance to treeline, aspect and steepness.

\section{Materials and methods}

\section{Study sites}

The study sites are spread out across the subalpine areas of the Swiss Alps. The Northern Alps are characterized by maritime climate with cool summers, moderately cold winters and more than 1,500 $\mathrm{mm}$ of precipitation per year. In contrast, the Central Alps receive $<1,200 \mathrm{~mm}$ precipitation per year and are typically characterized by hot and dry summers and cold winters. The climate in the Southern Alps is hot with relatively dry summers with occasional heavy rainfalls $(>1,200 \mathrm{~mm}$ of precipitation sum per year) and winters are moderately cold. This diverse climate on small scales within the Swiss Alps mixed with a complex and highly fragmented topography causes a high diversity in site conditions and climate that correspond to remarkable differences of the vegetation cover over short distances. However, with regard to the composition, subalpine forests in the Swiss Alps are often dominated by Norway spruce, occasionally mixed with Larix decidua and Pinus cembra, locally replaced by Pinus mugo ssp. mugo in drier regions.

\section{Data}

We used two complementary data sets to study the processes outlined above: (1) inventory data (National Forest
Inventory NFI; see also Krumm et al. 2011) and (2) dendroecologial data from field plots.

Inventory Data

About 5,400 forest sample plots were measured in each of the three inventory periods NFI 1 (1983-1985), NFI 2 (1993-1995) and NFI 3 (2004-2006). Across Switzerland, permanent sample plots were located on a regular grid of $1.4 \mathrm{~km} \times 1.4 \mathrm{~km}$, and different variables related to the stands and trees are recorded by field crews. Two concentric circles are used to sample individual trees: all living and fallen or standing dead trees are recorded (a) within a $200-\mathrm{m}^{2}$ circle for trees with a diameter at breast height $(\mathrm{DBH}) \geq 12 \mathrm{~cm}$ and (b) within a $500-\mathrm{m}^{2}$ circle for trees with a $\mathrm{DBH} \geq 36 \mathrm{~cm}$. A $50 \times 50$ interpretation area is used to assess site- and stand attributes (e.g. exposition, degree of coverage, etc.). The manual for the field survey of the NFI (Stierlin et al. 1994; Keller 2005) provides more detailed information.

Our study focused on 147 NFI plots meeting the following criteria (1) subalpine (between 1,600 and 2,100 m.a.s.1.), (2) high stem density [ $>400$ stems per ha with $\mathrm{DBH} \geq 12 \mathrm{~cm}$, degree of coverage "dense" to "moderately dense" (very small gaps possible)] (3) even aged (germination 100-120 years ago), (4) spruce dominated (at least $80 \%$ of the total number of trees $\geq 12 \mathrm{~cm}$ $\mathrm{DBH}$ ) and (5) unmanaged (not managed since at least 1933).

The variable "distance to potential treeline" was derived from the Swiss areal statistics GEOSTAT (Swiss Federal Agency of Statistics 1985), which provides information about location, elevation and land cover type of each grid point in a 100-m-wide cartesian coordinate system of Switzerland in a geographical information system (GIS). Each type of land cover is assigned to a grid point, which has been grouped within $10 \mathrm{~km} \times 10 \mathrm{~km}$ land area segments over the whole area. The groups have been analysed, and from each of these $100-\mathrm{km}^{2}$ areas, the topographic elevation of the highest point covered with forest has been extracted and defines the 'GIS tree line' for each of these square areas. This algorithm reduced the spatial resolution of the original GIS grid from 0.1 to $10 \mathrm{~km}$. With a spatial resolution of $10 \mathrm{~km}$, it is possible to remove information that reflects small-scale fluctuations of local growth conditions for trees. However, the resolution is still fine enough to capture regional differences in climatic treeline elevation (Körner and Paulsen 2004).

For analysing dead wood at the NFI plots, we used data from dead standing and fallen NFI sample trees, and we finally separated the study sites into those located on $\mathrm{N}$-facing (68 plots) and S-facing (79 plots) slopes. 
Field sites and dendrochronological analyses

Among the stands of selected NFI plots, we selected 20 plots for additional field surveys. The selection of these 20 plots have been made according to the following criteria: (1) subalpine (elevations between 1,700 and 2,100 m a.s.l., (2) spruce dominated (at least $80 \%$ ), (3) they have neither been actively treated nor any timber has been logged since at least 1933, (4) the stand structure of these plots is homogenous and dense (crown cover $>75 \%$, stem density $>400$ stems per ha with DBH $\geq 12 \mathrm{~cm}$ and an absence of gaps $>5 \mathrm{~m}$ width) and (5) we stratified the plots according to $\mathrm{N}$ exposure (10 plots) and $\mathrm{S}$ exposure (10 plots). These plots for additional field surveys and dendrochronological analysis were situated as close as possible from the corresponding NFI plots (where no dendroecologcial analysis was allowed).

Many young seedlings die as a result of competition but decompose quickly which makes it impossible to reconstruct the density of seedlings a few decades later. Therefore, we focused our analysis on trees that are taller than $3 \mathrm{~m}$ and larger than $10 \mathrm{~cm} \mathrm{DBH}$. The plots were $22 \mathrm{~m} \times 22 \mathrm{~m}$ and we cored all dead and alive trees for which coring was possible, according to their decomposition degree. We took a first core as close to the tree bottom as possible and a second one at breast height, perpendicular to the slope. Cores were glued on wooden boards, sanded and dated following the standard procedures of Stokes and Smiley (1968). Ring widths were measured and checked on a semi automatic measuring system (developed at the Institute of Forest Growth (IWW) in Freiburg, Germany) to the nearest $0.01 \mathrm{~mm}$. The computer program COFECHA (Holmes 1983) was used to detect measurement and crossdating errors. Each tree's ring width record was standardized and then averaged with the other trees' records to produce a mean stand chronology for each site (Cook et al. 1990; Fritts 1971). DplR package (Bunn 2010) for $R$ ( $\mathrm{R}$ development core team 2008) was used to process and plot the tree ring data.

\section{Statistical analysis}

All statistical analyses were performed using $\mathrm{R}$ ( $\mathrm{R}$ development core team 2008). We used repeated measures ANOVA to analyse how the independent variables aspect, distance to treeline and steepness influenced the dependent variables development of $\mathrm{BA}$, stems per ha and the occurrence of dead wood during the three survey periods.

Using the regression tree model "party" (Zeileis et al. 2005), we assessed which variables most influence the development of dead wood per hectare. Regression and classification trees (CART) are flexible and robust statistical tools that can explain non-linear relationships and are free of distributional assumptions (Vayssieres et al. 2000). The variation of every single variable is explained by splitting the data into more homogenous groups (Déath and Fabricius 2000). A regression tree is built by binary recursive partitioning and iteratively splits the data into increasingly more homogenous partitions. An algorithm determines the split, where the data is divided into two parts, and the sum of the squared deviations from the means is minimized (Déath and Fabricius 2000). The trees are pruned to avoid over-fitting and to exclude random effects caused by values, which are not representative for the majority of the data. A cost complexity factor, which defines the best fitting of the tree, is calculated by the statistical program. Breiman et al. (1984) describe tree fitting, pruning and cross-validation procedures in more detail.

\section{Results}

Analysis of the NFI plots

Overall BA increased in all distance classes to treeline in the unmanaged forests under study. The closer the distance to treeline the larger the absolute increases in BA per ha in the last 20 years. The greatest increase in absolute values occurred in areas within $300 \mathrm{~m}$ distance of treeline (average $=6.7 \mathrm{~m}^{2} \mathrm{ha}^{-1}$, range: $3.5-10 \mathrm{~m}^{2} \mathrm{ha}^{-1}$ ), whereas the increase in BA at distances between 300 and $600 \mathrm{~m}$ was lower (average $6.05 \mathrm{~m}^{2} \mathrm{ha}^{-1}$, range: $4.5-7 \mathrm{~m}^{2} \mathrm{ha}^{-1}$ ) and lowest between 600 and $900 \mathrm{~m}$ distance to treeline (Fig. 1a). In contrast, stem number slightly decreased in areas within $300 \mathrm{~m}$ of treeline with the period of observations but increased in forests from 300 to $900 \mathrm{~m}$ distance of treeline (Fig. 1b).

Whereas BA was similar on both aspects at the beginning of the survey (1983), it increased more on northern compared with southern slopes during the 20 years of observation (Fig. 2a). The number of stems per ha slightly increased during the survey periods on $\mathrm{N}$-slopes, whereas on S-slopes the number of stems strongly decreased (Fig. 2b).

During the last 20 years, the BA of dead wood and the number of dead stems per ha increased substantially. The total BA of dead wood was higher in south-facing compared with north-facing forests (Fig. 3a); however, the number of dead stems increased more on northern than on southern slopes (Fig. 3b). In $75 \%$ of the forests, the amount of dead wood increased or remained constant during the last 20 years. The mean quantity of dead wood was $3.6 \mathrm{~m}^{2} \mathrm{ha}^{-1}$ in NFI 2 and $5.0 \mathrm{~m}^{2} \mathrm{ha}^{-1}$ in NFI 3 , whereas the number of dead stems increased from 41 dead stems in NFI 2 up to 62 dead stems per ha in NFI 3. On 
Fig. 1 Change in basal area per ha as a function of distance to treeline (a), and change of the number of stems per hectare as a function of the distance to treeline $(\mathbf{b})$
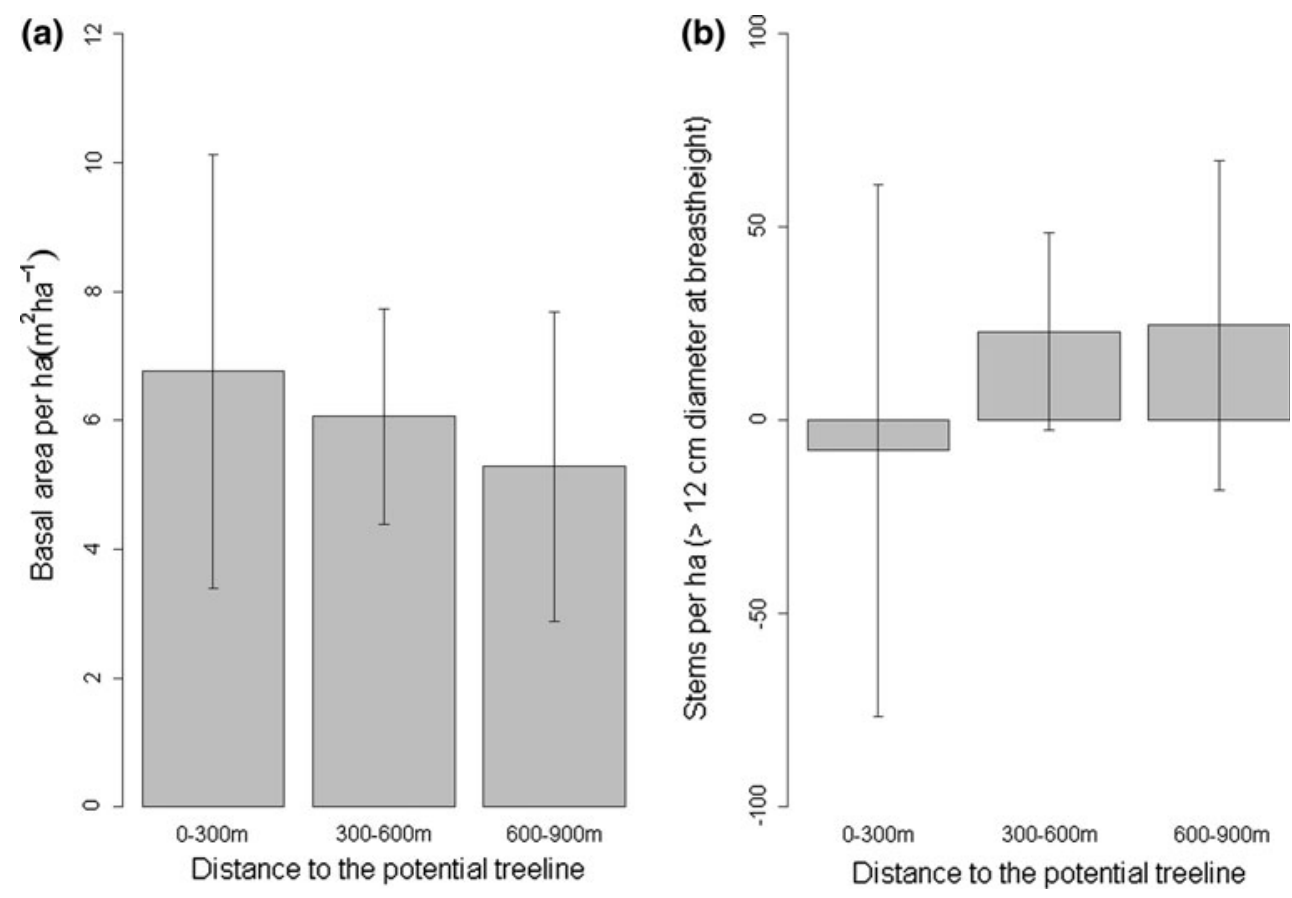

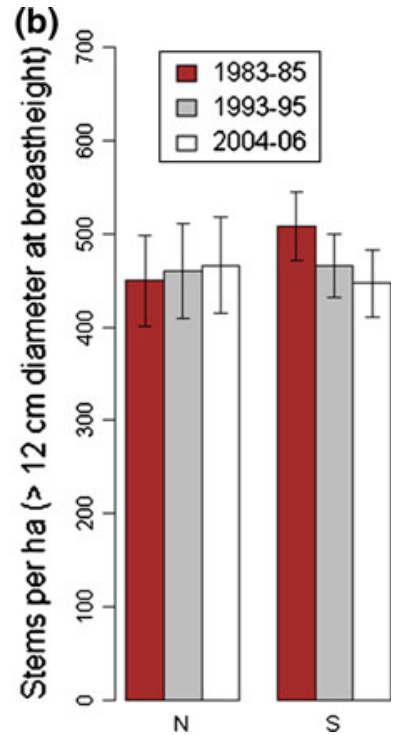

Fig. 2 Basal area per hectare (a) on northern $(N)$ and southern $(S)$ slopes based on three different inventory periods. Number of stems per hectare (b) on northern and southern slopes based on three different inventory periods

steeper slopes $\left(>30^{\circ}\right)$, the occurrence of dead wood was significantly more pronounced than on less steep slopes, whereas aspect and the distance to treeline did not exhibit strong effects on the occurrence of dead wood (Fig. 4).

Analysis of the 20 field plots

The sampled trees germinated with few exceptions in a time span of 20-40 years and reached mean ages between
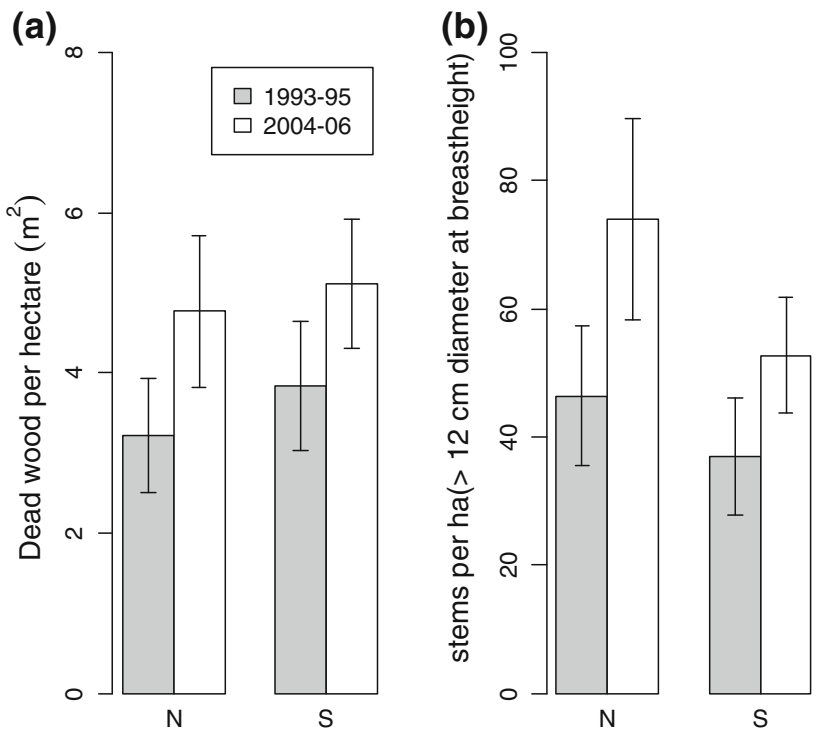

Fig. 3 Dead wood per hectare on northern $(N)$ and southern $(S)$ slopes for the two recent inventory periods (a). Dead stems per hectare ( $>12 \mathrm{~cm}$ diameter at breastheight) on northern and southern slopes for the two recent inventory periods (b)

70 and 150 years (Table 1). Due to very slow initial growth rates and the fact that tree ages are reported as ages at coring height (as close to the bottom as possible), the actual tree ages might be underestimated by up to 20 years (Wong and Lertzman 2001). One-third of the surveyed trees were dead; however, the dead trees accounted only for a smaller portion of overall tree volume. BA of dead wood accounted for $10 \%$ of total BA across sites, but the mean number of dead trees across all sites was $36 \%$. The total mean wood 


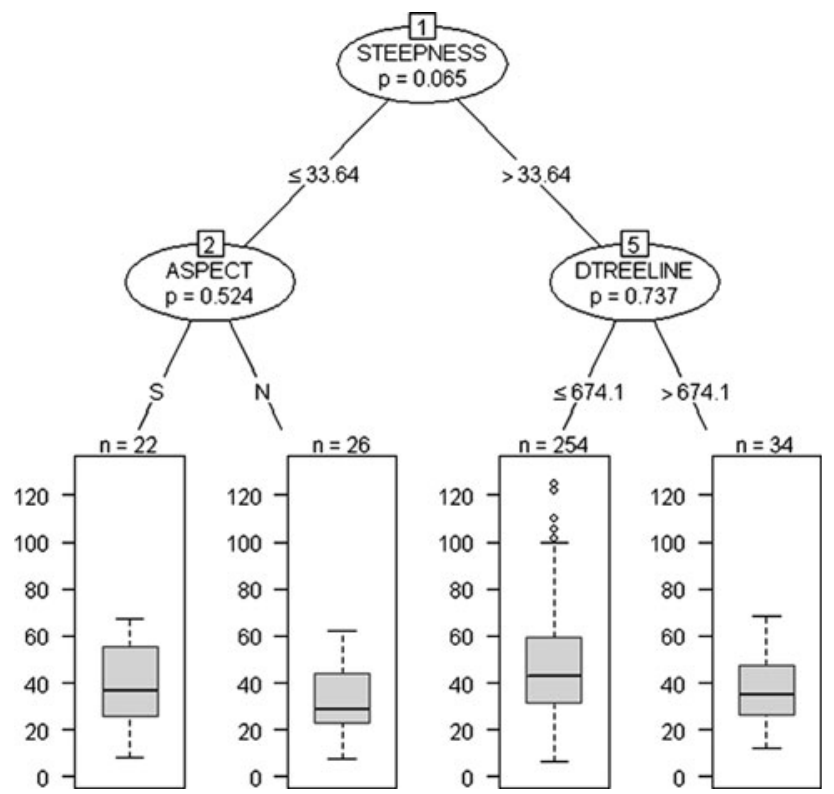

Fig. 4 Regression tree which illustrates the most important variables influencing the occurrence of dead wood. The response variable is displayed in the bars at the bottom of the tree and the $n$ value refers to the number of plots which are explained by the corresponding node, the bars display the median BA, the standard deviation and the variance

volume was quite high $\left(776 \mathrm{~m}^{3}\right.$ per ha) compared with similar forests of other regions (compare Korpel (1995)) (Fig. 5).

Tree ring chronologies revealed clear differences in the patterns of from N- and S-facing forests (Fig. 6a, b). Tree ring growth cumulated in southern forests after 45-60 years (Fig. 6a) and thereafter decreased. After 20 years of decreasing mean ring widths, ring growth recovered and did no longer decrease. Chronologies from north-facing slopes cumulated after approximately 70 years (Fig. 6b) and then decreased until today. The absolute decrease in the tree ring widths on northern slopes was more pronounced than on southern slopes and was ongoing until the time of sampling. However, the amount of dead wood measured in southfacing forests (NFI3) was higher than in north-facing forests. When only dead trees are considered (Fig. 7b), tree ring chronologies from dead trees on S-slopes showed fast initial growth and peak after 40 years before growth decreased for $\sim 20$ years. After a second, less pronounced growth increase, growth of these trees decreased again strongly for ca 30 years until the trees finally die (Fig. 7a). Initial growth increases in dead trees on $\mathrm{N}$-facing slopes was not as strong as on S-facing slopes but also peaked after 40 years. After a growth decrease in ca. 40 years, growth of these dead trees on $\mathrm{N}$-facing slopes increased again strongly during the last 20 years before the trees die (Fig. $7 \mathrm{~b}$ ).

The field plots did not exhibit differences in mortality rates of trees on north- versus south-facing slopes
(Table 2). In general, mortality increased within the last 100 years, but mainly in the second half of the century. In the mid seventies, a first considerable increase in mortality was observed before mortality peaked in 1993 and 1994. After the year 2000, mortality increased again with a very pronounced peak in the year of sampling (2008; Fig. 5). The raw ring width curves of the trees that died prior to 2008 were characterized by slower growth from the very beginning of their establishment compared with the surviving trees (Fig. 8).

\section{Discussion}

Previous work has shown that in dense, unmanaged subalpine forest stands of the Swiss Alps, overall BA has increased while tree density has remained unchanged over the past 20 years (Krumm et al. 2011). Our current analysis provides a more nuanced view into forest structural changes in these ecosystems. The results indicate that forests in the stem exclusion phase are widespread in the subalpine zone of the Swiss Alps and that the ongoing increase in BA has been most pronounced in forests near potential treeline (Pecher et al. 2011). Site factors, such as slope steepness, distance to potential treeline and, most importantly, aspect, influence temperature and mechanical impacts and the rate of tree growth and consequently the structural development of forests.

Competition began earlier on $\mathrm{S}$ - than on $\mathrm{N}$-facing slopes; however, the amount of dead wood was higher on $\mathrm{N}$-facing than $\mathrm{S}$-facing slopes. Mortality has increased over the last 20 years and is likely to continue to increase over the next 20-50 years due to intensive competition processes. Trees, which have died, were generally predisposed to die from the beginning of their establishment due to initially slow growth rates and presumably consequentially decreased competitive ability.

\section{Forest development}

At elevations near treeline or at other unfavourable sites, "stem exclusion" and "breakup" phases may be bypassed and stand development may instead be characterized by gradually increasing stand density (Peet 2000). Harsh environmental conditions such as wind, snow and cold temperatures can indeed lead to fragmented and/or lowdensity forest structure near treeline in the Alps (Harsch et al. 2009; Körner 2003). Despite the high-elevation setting, the current research indicates that stem exclusion phases were not bypassed in the subalpine forests considered in this study. The increase in BA per ha (Fig. 2a, b) likely was associated with increased tree establishment in forest gaps near treeline (Körner 2003), due to land abandonment 
Table 1 Partition, wood pool and basal area (BA) of live and dead trees per hectare (numbers have been scaled up to ha) in the 20 field plots

\begin{tabular}{|c|c|c|c|c|c|c|c|c|}
\hline Site & $\begin{array}{l}\% \text { Alive } \\
\text { trees }\end{array}$ & $\begin{array}{l}\% \text { Dead } \\
\text { trees }\end{array}$ & Aspect & $\begin{array}{l}\text { BA per } \\
\text { ha }\left(\mathrm{m}^{2}\right)\end{array}$ & $\begin{array}{l}\text { Total wood } \\
\text { volume }\left(\mathrm{m}^{3}\right)\end{array}$ & $\begin{array}{l}\text { Wood volume } \\
\text { alive }\left(\mathrm{m}^{3}\right)\end{array}$ & $\begin{array}{l}\text { Wood volume } \\
\text { dead }\left(\mathrm{m}^{3}\right)\end{array}$ & $\begin{array}{l}\text { Stand } \\
\text { origin }\end{array}$ \\
\hline Andeer & 58 & 42 & $\mathrm{~N}$ & 69 & 708 & 675 & 33 & $1890-1920$ \\
\hline Ausserferrera & 49 & 51 & $\mathrm{~S}$ & 89 & 943 & 824 & 119 & $1860-1890$ \\
\hline Buffalora/Soazza & 48 & 52 & $\mathrm{~S}$ & 121 & 1,028 & 588 & 440 & 1910-1930 \\
\hline Dangio/Olivone & 84 & 16 & $\mathrm{~S}$ & 63 & 521 & 519 & 2 & $1920-1940$ \\
\hline Derborence & 67 & 33 & $\mathrm{~S}$ & 82 & 711 & 692 & 19 & $1920-1940$ \\
\hline Flumserberge & 79 & 21 & $\mathrm{~N}$ & 63 & 642 & 614 & 28 & $1890-1920$ \\
\hline Grindelwald/Alpiglen & 65 & 35 & $\mathrm{~N}$ & 93 & 719 & 670 & 49 & 1910-1930 \\
\hline Davos/Aebiwald & 71 & 29 & $\mathrm{~N}$ & 89 & 885 & 760 & 87 & $1860-1875$ \\
\hline Valzeina/Scaera & 54 & 46 & $\mathrm{~N}$ & 56 & 514 & 472 & 41 & 1915-1930 \\
\hline Mönchalp/Litziwald & 59 & 41 & $\mathrm{~N}$ & 86 & 826 & 588 & 238 & $1870-1890$ \\
\hline Mönchalp/Trittwald & 73 & 27 & $\mathrm{~S}$ & 78 & 506 & 499 & 7 & $1890-1930$ \\
\hline Savognin & 75 & 25 & $\mathrm{~S}$ & 108 & 1,003 & 873 & 130 & $1890-1915$ \\
\hline Lenz/Val Meltger & 86 & 14 & $\mathrm{~S}$ & 78 & 605 & 547 & 59 & $1890-1920$ \\
\hline Safien S & 59 & 41 & $\mathrm{~S}$ & 73 & 718 & 644 & 74 & 1880-1910 \\
\hline Safien N & 66 & 34 & $\mathrm{~N}$ & 59 & 621 & 600 & 21 & $1900-1920$ \\
\hline Stels & 72 & 28 & $\mathrm{~N}$ & 103 & 864 & 844 & 20 & $1890-1915$ \\
\hline Turtmann N & 62 & 38 & $\mathrm{~N}$ & 61 & 552 & 507 & 45 & $1850-1870$ \\
\hline Turtmann S & 50 & 50 & $\mathrm{~S}$ & 83 & 800 & 757 & 43 & $1900-1920$ \\
\hline Vals & 60 & 40 & $\mathrm{~N}$ & 117 & 892 & 863 & 29 & $1890-1920$ \\
\hline Wengen & 55 & 45 & $\mathrm{~S}$ & 134 & 1,471 & 1,320 & 152 & 1880-1900 \\
\hline
\end{tabular}

Dates of the stand origin and aspects of the field plots

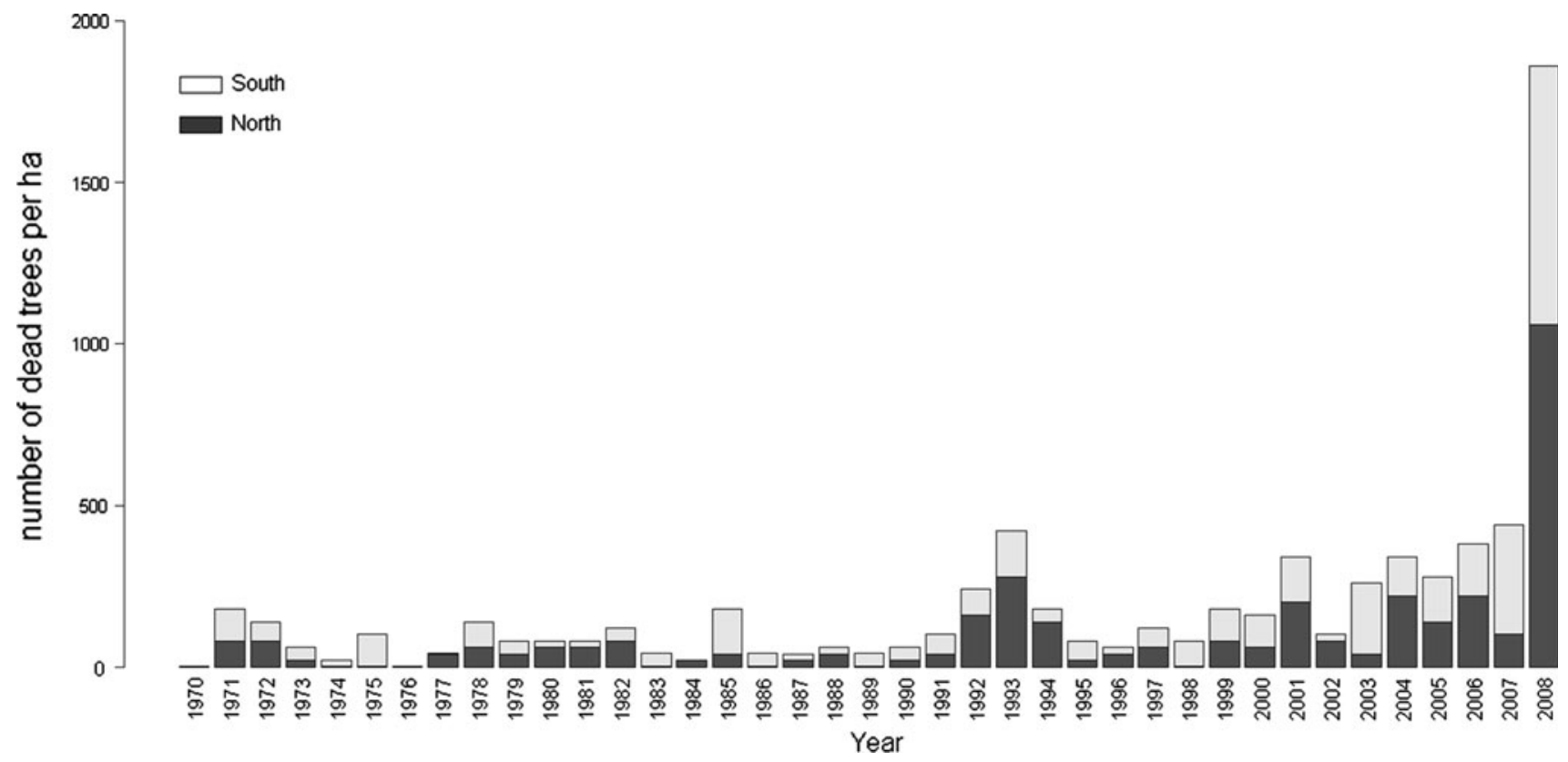

Fig. 5 Number of dead trees per hectare in the 20 sample plots on northern slopes (dark bar parts) and on southern slopes (bright bar parts)

(Gehrig-Fasel et al. 2007; Gellrich et al. 2007; Gellrich and Zimmermann 2007; Ott 1978). Increased air temperatures since the end of the Little Ice Age (i.e. after 1880) of at least
0.8-1.0 ${ }^{\circ} \mathrm{C}$ (Rebetez 2006, Beniston et al. 1997) and accelerated warming and longer growing seasons over the past 30 years (Rebetez et al. 2009) are also likely to have 
(a)

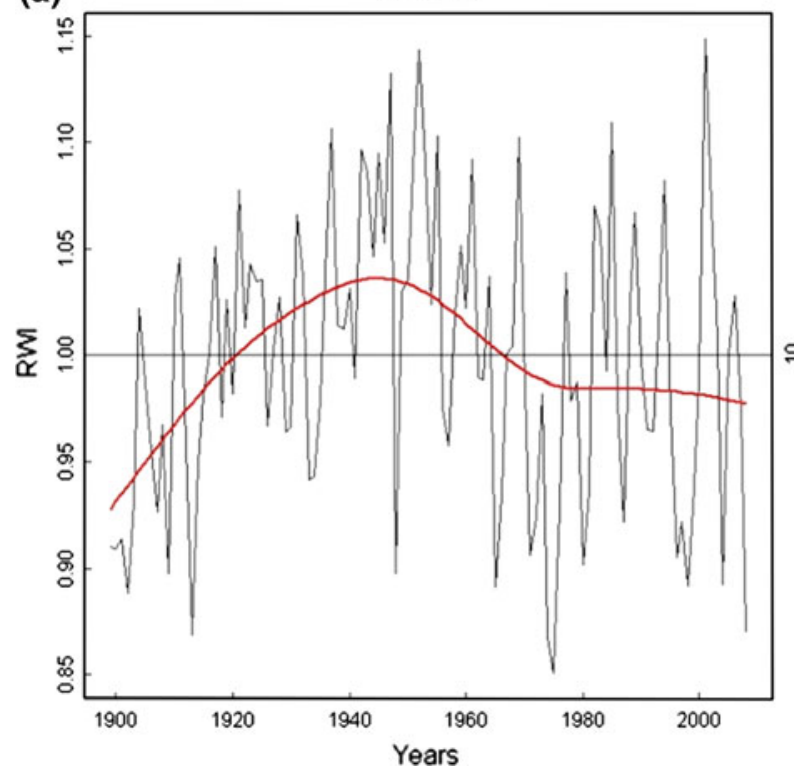

(b)

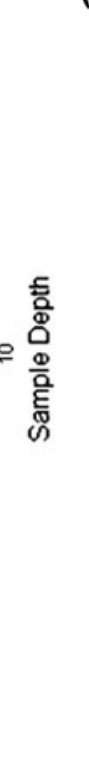

ALNstd

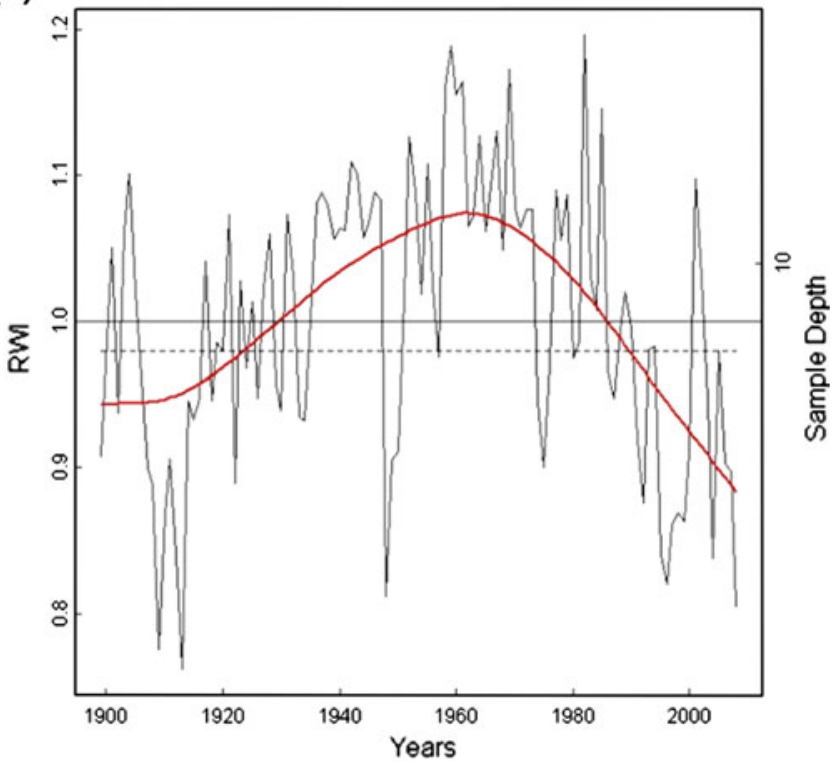

Fig. 6 Raw ring width chronologies for S-slopes (ALSstd) and N-facing slopes (ALNstd) are displayed with the dark line. The tree ring series have been standardized and detrended with a spline (67-year cutoff) and are shown with the red line. (Color figure online)

(a)

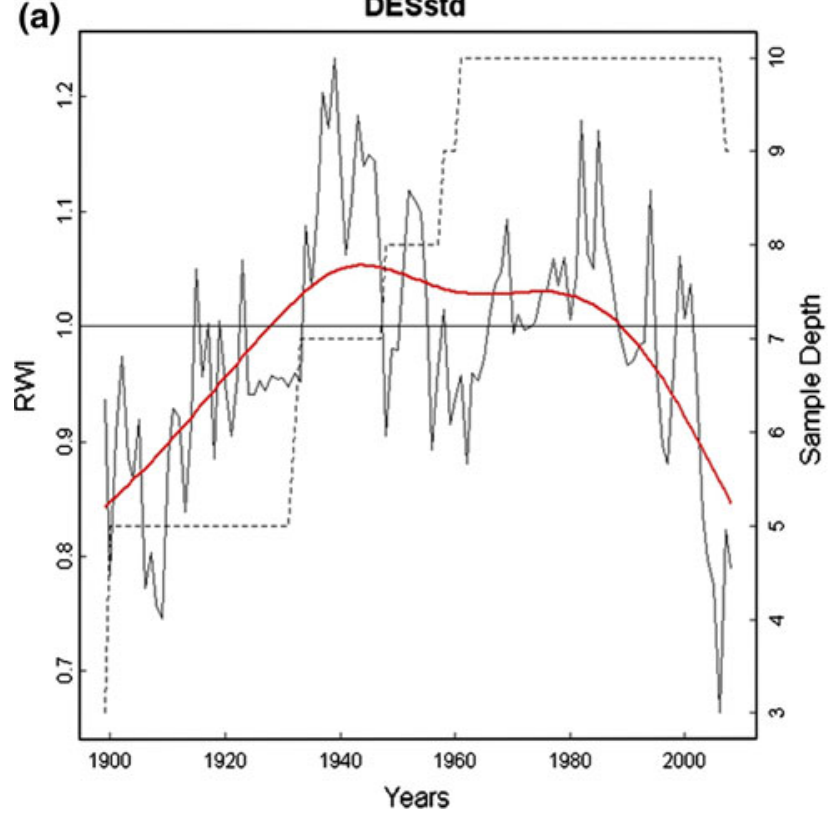

Fig. 7 Raw ring width chronologies for all dead trees in the study plots on S-facing slopes (DESstd) and $\mathrm{N}$-slopes (DENstd) are displayed with the dark line. The ring series have been standardized and detrended with

substantially contributed to increased tree growth near the alpine treeline. In fact, $P$. abies in particular, which is the dominating tree species in most subalpine regions of the Swiss Alps, has the ability to respond quickly to warmer temperatures in spring and early summer with increased photosynthesis and accelerated growth (Schmidt-Vogt 1987). Climate warming has a clear effect on tree growth, (b)

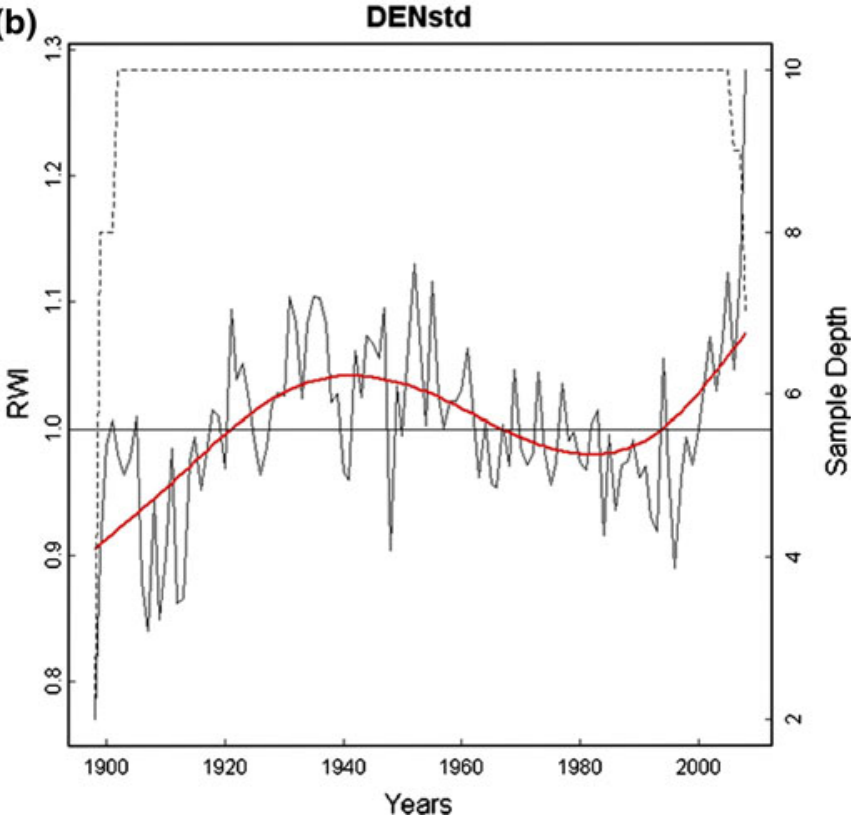

a spline (67 cutoff), which is displayed with the red line. (Color figure online)

but this effect is contingent on the consequences of land abandonment (Kulakowski et al. 2011). It also differs across sites with varying consequences for treeline sites compared with lower subalpine forests (Wieser and Tausz 2007). Stem exclusion is likely to be more predominant closer to potential treeline in the near future, where the greatest increase in BA has occurred over the past decades (Table 1). 


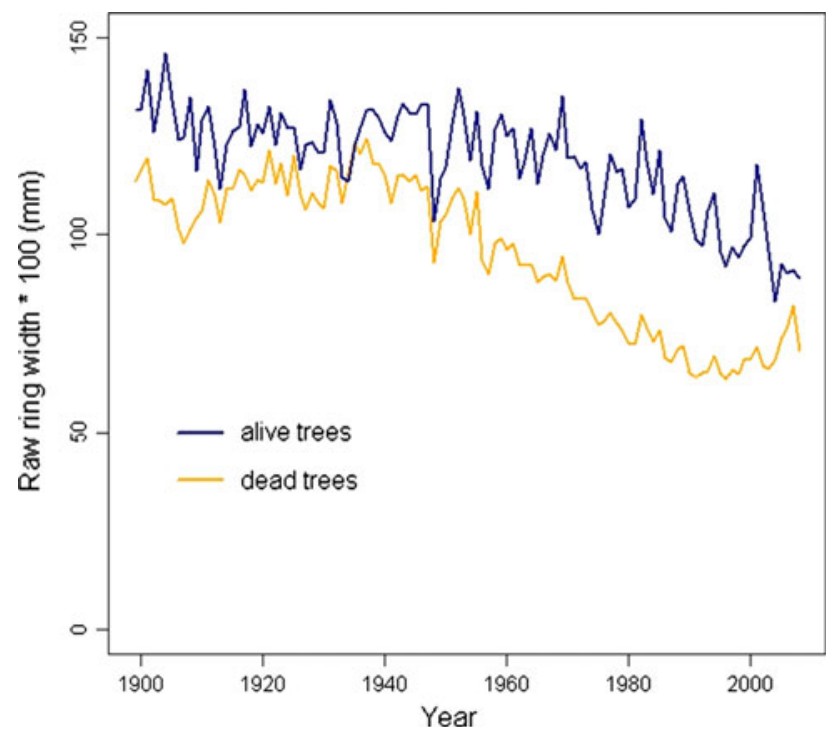

Fig. 8 Raw ring width curves of all live (blue; $n=1,604)$ and dead (orange; $n=413$ ) trees cored on the field plots. (Color figure online)

North- versus south-facing slopes: effect on stem exclusion process

In the northern hemisphere, the development of forests on north-facing slopes is generally slower compared with the development on S-facing slopes. In the Swiss Alps, most $\mathrm{N}$-facing stands are still in a phase characterized by increasing BA and density (Fig. 2a, b). This contrasts with forests on $\mathrm{S}$-facing slopes, in which increases in BA have been less pronounced and stem density has been decreasing. Reasons for different predominance of stands in the stem exclusion stage on north- versus south-facing slopes are various: (1) there are important differences in the land use history of $\mathrm{N}$ - and S-facing slopes: S-facing slopes were preferred as pasture land (Ott 1978; Däniker 1923) and were abandoned later than $\mathrm{N}$-facing slopes. Although partly offset by differences in solar radiation (see point 3 ), these historical differences in land use can potentially explain different stages of development; (2) Avalanches occur more often in forested terrain on north-facing slopes, where snow interception of trees is less effective and weak layers of surface hoar are more likely (Bebi et al. 2001); unpublished data SLF); and (3) Root and shoot growth are strongly temperature dependent (Tranquillini 1979), and the vegetation period of young trees close to treeline is at least 3-4 weeks longer on eastern to S-slopes versus $\mathrm{N}$-slopes, whereas the above-mentioned differences in root growth are much greater than in shoot growth (Häsler et al. 1999). As a consequence and because competition generally favours fast-growing trees in forests that are less resource limited (Kuenstler et al. 2011, Herms and Mattson
1992, Welden and Slauson 1986), competition begins earlier and is more intense on S-facing slopes (Fig. 6a, b).

In later developmental stages, that is, when trees are older than roughly 50 years, different growth and mortality pattern on $\mathrm{N}$ - versus $\mathrm{S}$ - facing slopes reflect differences in aboveground versus belowground competition. As warmth and light is generally scarcer on $\mathrm{N}$-facing slopes, aboveground competition is more intense after crown closure of trees on $\mathrm{N}$-facing slopes. As a consequence, trees die at earlier ages in lower diameter classes compared with trees growing on south-facing slopes (Fig. 6). In contrast, belowground competition for soil water is probably higher on S-facing slopes, where water is more limited due to earlier snowmelt and higher soil temperatures (Oberbauer and Billings 1981).

The growth curves of trees that died (Fig. 7a, b) display a strikingly different pattern, which could partly be explained by different growth and competition processes on $\mathrm{N}$ - versus $\mathrm{S}$-facing slopes. Trees on S-facing slopes exhibited faster initial growth compared with $\mathrm{N}$-facing slopes where initial growth was slower. Many trees on $\mathrm{N}$-facing slopes showed increased growth rates as a result of higher temperatures over the past decade (Fig. 7b), indicating that trees could react in the cold-limited environment of $\mathrm{N}$-facing slopes to the recent warm phases and increase their relative tree growth whereas trees on S-facing slopes did not show significant reactions.

In the northern hemisphere, $\mathrm{N}$-facing slopes are generally characterized by higher soil moisture which favours faster wood decomposition, though this effect is most likely offset by lower temperatures compared with drier conditions on S-facing slopes (Bardgett and Wardle 2010; Progar et al. 2000; Brown et al. 1998). Our results suggest slower decomposition rates on $\mathrm{N}$-slopes due to lower temperatures and consequential higher rates of accumulation of dead wood (Fig. 3a, b). In our stands, most trees died while standing and not because of wind throw or snow breakage, thus decomposition likely is slower than when tree are lying on the forest floor. In addition, most of the dead trees died at a young age and did not exhibit any heartrot at time of death, a factor which slows down decomposition (Kueppers et al. 2004; Holeksa 2001; Brown et al. 1998). Influences on decomposition rates can change over small distances due to climatic variations and different microsites (Bardgett and Wardle 2010; Zielonka 2006; Häsler et al. 1999) which makes it difficult to draw general conclusions.

On $\mathrm{N}$-facing slopes stem exclusion processes are ongoing and the number of dead stems is still increasing. This process will likely continue over the next decades. These findings are supported by an earlier growth culmination of tree rings on $\mathrm{S}$ - slopes than on $\mathrm{N}$-slopes and consequently an earlier beginning of competition on 
Table 2 Statistical analysis of the repeated measures anova according to aspect and the development of dead wood

\begin{tabular}{llrrr}
\hline & numDF & denDF & $F$ value & $p$ value \\
\hline Aspect & & & & \\
Stems & & & & \\
$\quad$ Intercept) & 1 & 290 & 280.30283 & $<0.0001$ \\
ASPECT & 1 & 144 & 0.21664 & 0.6423 \\
NFI & 2 & 290 & 0.66485 & 0.5151 \\
Basal area & & & & \\
(Intercept) & 1 & 290 & 574.0267 & $<0.0001$ \\
ASPECT & 1 & 144 & 0.0291 & 0.8648 \\
NFI & 2 & 290 & 17.2991 & $<0.0001^{*}$ \\
Dead wood & & & & \\
Stems & & & & \\
(Intercept) & 1 & 290 & 43.50492 & $<0.0001$ \\
ASPECT & 1 & 144 & 0.63285 & 0.4276 \\
NFI & 2 & 290 & 20.42546 & $<0.0001^{*}$ \\
Basal area & & & & \\
(Intercept) & 1 & 290 & 62.59511 & $<0.0001$ \\
ASPECT & 1 & 144 & 0.52514 & 0.4698 \\
NFI & 2 & 290 & 28.21161 & $<0.0001^{*}$ \\
\hline
\end{tabular}

$* P<0.05, * * P<0.01$, *** $P<0.001$

S-facing slopes. Competition lead to a decrease in annual ring widths and after 20-40 years tree ring width stopped decreasing. They are likely to increase again, due to more abundant availability of resources, which may come about from self-thinning processes occurring in waves, as suggested by Oliver and Larson (1996). The idea that competition starts earlier on south-facing slopes is consistent with our analysis of the NFI-data, which found marked increases of BA and a slight increase of stem density, both of which were more pronounced on S-facing slopes.

\section{Disturbances}

Natural disturbances over the last 20 years were generally rare in the examined forests. The windstorms "Vivian/ Wiebke" (1990) and "Lothar" (2000) affected extensive areas across central Europe, but both did not affect our study areas located above $1,600 \mathrm{~m}$. Thus, they cannot be responsible for the increasing CWD in our sample plots (Putallaz 2011; Fankhauser 2011; Schmidtke and Scherrer 1997). We recognize that it is possible that the increase in density could be partly explained by forests that were disturbed by wind, snow breakage, or other agents more than 20 years ago and were therefore in a state of postdisturbance development. However, tree ring data, which allowed us to investigate long-term developments in 20 stands, also did not show any evidence of intermediate to large-scale disturbances.

\section{Competition}

In our study, we found that trees that exhibited slow initial growth died earlier during initial stages of stand development compared with faster growing neighbours of the same age (Fig. 8). This was most likely due to the fact that faster-growing trees reached the canopy earlier and were better able to compete for light and other resources. Trees that grow slowly in dense stands are often suppressed and act as a reserve for dominating trees. However, the ability of suppressed Norway spruce trees to expand their crowns into the canopy is limited and reduces after the trees reached an age of 40-50 years (Fig. 8) when they reach pole sizes (12-18 cm DBH) (Waring 1987). The physiological maintenance costs, particularly the respiration of live tissue of suppressed trees, increase rapidly with a growing stem (Waring 1987). As a consequence, such trees are not able to persist long due to low growth rates (Kaufmann 1996) and are predisposed to die earlier than others when they exhibit initial slower growth than neighbouring trees (Fig. 8). This is in contrast to mortality processes in old-growth subalpine forests of lower density, where young trees are establishing between older ones. In that case, trees that grow slowly in the beginning live longer than trees that initially grow more rapidly (Bigler 2003; Ott 1978).

\section{Mortality}

The main reason for increasing dead wood in the dense forests under study was increasing competition. The trend of increasing mortality observed in the inventory data was confirmed by our field plots that exhibited two peaks of mortality in 1993/1994 and 2008. These increased mortality rates were unrelated to any evidence of disturbances or biotic derived mortality (e.g. bark beetle) (Fig. 5). Dead wood is a crucial component for the natural dynamics of forests. The presence of dead wood is critical for the habitat of many different plant and animal species (Bütler and Schlaepfer 2004) and, particularly in high elevations, crucial for the establishment of young trees (Zielonka 2006; Ott et al. 1991).

The overall BA of dead wood has generally increased in the forests under investigation and was most abundant on steep slopes (Fig. 4). The reason for these findings could be that on steep slopes management generally ceased earlier than on less steep slopes. Therefore, the stands were in a more advanced development stages (stem exclusion phase) compared with the ones on flatter slopes. Eventually, these stands may also enter "old-growth" stages before other stands. The BA of dead wood is generally higher on S-slopes than on N-slopes (Fig. 3a). Although this difference was not significant, if we account for the different dimensions of the dead trees, there is obviously a crucial 
difference between dead trees on $\mathrm{N}$-slopes, which die while smaller on average, versus the dead wood on S-slopes (Herms and Mattson 1992; Harmon et al. 1986).

\section{Conclusions}

Although subalpine forests in the Alps have generally an open canopy, stands in the stem exclusion phase are also widespread and their abundance has been increasing. Our results show that the speed and intensity of competitive processes depends on steepness, aspect and the distance to potential treeline. The rate of tree growth has already culminated in some stands, whereas the rate of growth in most other stands is likely to culminate within the next few decades.

Tree growth and forest structural development were generally slower on $\mathrm{N}$ - facing slopes compared with $\mathrm{S}$-facing slopes. Consequently, competition started at least 20-40 years earlier on S-facing forests leading to an earlier increase in mortality rates driven by self-thinning. However, the density of dead trees was generally higher on $\mathrm{N}$-slopes because trees generally died at a younger age on $\mathrm{N}$-slopes and decay processes are generally slower.

Suppressed trees during the stem exclusion stage may be a reserve for dying dominant trees in the canopy, for roughly 50 years. However, these suppressed trees are often predisposed to die early if they exhibit lower initial growth rates compared with neighbouring trees.

This study demonstrates how both environmental heterogeneity and management history can influence the spatiotemporal structural development of forest ecosystems.

Acknowledgments The authors would like to thank the VELUX foundation (Switzerland) for financing this study. We want to thank Veronika Stöckli, Markus Huber and Andreas Zingg and two anonymous reviewers for careful review and valuable comments on the manuscript. The Institute of Forest Growth in Freiburg (Germany) provided equipment, software and space for the tree ring measurements, and Clemens Koch and Felix Baab supported us with technical advice. Mirjam Ackermann and Antoine Vuilloud helped us with the data sampling in the field, and Andrea Baumann, Flavien Roullier, Maxime Pattaroni, Nikolay Tsvetanov and Neli Nikolova helped with the tree ring measurements. Momchil Panayotov developed with us the sampling methods and helped us to improve our work with numerous suggestions and comments.

\section{References}

Antos JA, Parish R (2002) Dynamics of an old-growth, fire-initiated, subalpine forest in southern interior British Columbia: tree size, age, and spatial structure. Can J For Res 32:1935-1946

Antos JA, Guest HJ, Parish R (2005) The tree seedling bank in an ancient montane forest: stress tolerators in a productive habitat. J Ecol 93(3):536-543. doi:10.1111/j.1365-2745.2005.00968.x
Aulitzky H (1984) The microclimatic conditions in a subalpine forest as basis for the management. GeoJournal 8(3):277-281

Barbour MG, Billings WD (1988) North American terrestrial vegetation. Cambridge University Press, New York

Bardgett DR, Wardle AD (2010) Aboveground-belowground linkages. Oxford University Press, Oxford

Bebi P, Kienast F, Schönenberger W (2001) Assessing structures in mountain forests as a basis for investigating the forests' dynamics and protective function. For Ecol Manag 145:3-14

Beniston M, Diaz HF, Bradley RS (1997) Climatic change at high elevation sites: an overview. Clim Chang 36:233-251

Bigler C (2003) Growth-dependent tree mortality: ecological processes and modeling approaches based on tree-ring data. Diss, Zürich

Brändli U-B (2010) Schweizerisches Landesforstinventar. Ergebnisse der dritten Erhebung 2004-2006. Eidgenössische Forschungsanstalt für Wald, Schnee und Landschaft. Bern, Bundesamt für Umwelt, Wald und Landschaft, Birmensdorf

Brang P (2004) Biologische Rationalisierung im Waldbau. Jahrestagung der Sektion Waldbau im Deutschen Verband Forstlicher Forschungsanstalten. In: Jahrestagung der Sektion Waldbau im Deutschen Verband Forstlicher Forschungsanstalten. Birmensdorf, 2004

Breiman L, Friedman J, Stone JC, Olshen RA (1984) Classification and regression trees. Belmont, California

Brown MP, Shepperd DW, Mata AS, McClain LD (1998) Longevity of windthrown $\operatorname{logs}$ in a subalpine forest of central Colorado. Can J For Res 28:932-936

Bunn AG (2010) Statistical and visual crossdating in R using the dplR library. Dendrochronologia 28(4):251-258

Bütler R, Schlaepfer R (2004) Wie viel Totholz braucht der Wald? Schweizerische Zeitschrift für Forstwesen 155(2):31-37

Chen HYH, Popadiouk RV (2002) Dynamics of North American boreal mixedwoods. Environ Rev 10:137-166

Cook ER, Briffa K, Shiyatov S, Mazepa V (1990) Tree-ring standardization and growth-trend estimation. In: Cook ER, Kairiukstis AL (eds) Methods of dendrochronology: applications in the environmental sciences. Kluwer, Dordrecht, pp 104-123

Cumming SG, Schmiegelow FKA, Burton J (2000) Gap dynamics in boreal aspen stands: is the forest older than we think? Ecol Appl 10(3):744-759

Däniker A (1923) Biologische Studien über Baum- und Waldgrenze, insbesondere über die klimatischen Ursachen und deren $\mathrm{Zu}-$ sammenhänge, vol 68. Vierteljahresschrift Naturforschende Gesellschaft Zürich

Das A, Battles J, Stephenson NL, van Mantgem PJ (2011) The contribution of competition to tree mortality in old-growth coniferous forests. For Ecol Manag 261(7):1203-1213

Déath G, Fabricius KE (2000) Classification and regression trees: a powerful yet simple technique for ecological data analysis. Ecology 81(11):3178-3192

Fankhauser M (2011) Lawinenschutzwirkung auf Vivian-Windwurfflächen: Stand der Verjüngung 20 Jahre nach dem Sturmereignis im Dezember 2010. Bachelor, Bern

Frehner M, Wasser B, Schwitter R (2005) Nachhaltigkeit und Erfolgskontrolle im Schutzwald NaiS. Wegleitung für Pflegemassnahmen in Wäldern mit Schutzfunktion. Bundesamt für Umwelt, Wald und Landschaft. Bern

Fritts CH (1971) Dendroclimatology and dendroecology. Quat Res 1:419-449

Gehrig-Fasel J (2007) Treeline and climate change: analyzing and modeling patterns and shifts in the Swiss Alps. Doctoral Thesis, Universite de Lausanne, Lausanne

Gehrig-Fasel J, Guisan A, Zimmermann NE (2007) Tree line shifts in the Swiss Alps: climate change or land abandonment? J Veg Sci 18:571-582 
Gellrich M, Zimmermann NE (2007) Investigating the regional-scale pattern of agricultural land abandonment in the Swiss mountains: a spatial statistical modelling approach. Landsc Urban Plan 79:65-76

Gellrich M, Baur P, Koch B, Zimmermann NE (2007) Agricultural land abandonment and natural forest re-growth in the Swiss mountains: a spatially explicit economic analysis. Agric Ecosyst Environ 118:93-108

Grimm V, Wissel C (1997) Babel, or the ecological stability discussions: an inventory and analysis of terminology and a guide for avoiding confusion. Oecologia 109:323-334

Harmon ME, Franklin JF, Swanson FJ, Sollins P, Gregory SV, Lattin JD, Anderson NH, Cline SP, Aumen NG, Sedell JR, Lienkaemper GW, Cromack K Jr, Cummins KW (1986) Ecology of coarse woody debris in temperate ecosystems. In: MacFadyen A, Ford ED (eds) Advances in ecological research, vol 15. Academic Press, New York, pp 133-302

Harsch AM, Hulme PP, McGlone SM, Duncan PR (2009) Are treelines advancing? A global meta-analysis of treeline response to climate warming. Ecol Lett 12:1040-1049

Häsler R, Streule A, Turner H (1999) Shoot and root growth of young Larix decidua in contrasting microenvironments near the alpine timberline. Phyton 39(4):47-52

Herms DA, Mattson WJ (1992) The dilemma of plants: to grow or defend. Q Rev Biol 67(3):283-335

Holeksa J (2001) Coarse woody debris in a Carpathian subalpine spruce forest. Forstwissenschaftliches Centralblatt 120(1):256-270. doi: $10.1007 / \mathrm{bf02796097}$

Holmes LR (1983) Computer-assisted quality control in tree-ring dating and measurement. Tree-Ring Bull 43:69-75

Kaufmann EM (1996) To live fast or not: growth, vigor and longevity of old-growth ponderosa pine and lodgepole pine trees. Tree Physiol 16:139-144

Keller M (2005) Schweizerisches Landesforstinventar. Anleitung für die Feldaufnahmen der Erhebung 2004-2007. WSL, Birmensdorf

Körner C (2003) Alpine plant life: functional plant ecology of high mountain ecosystems, 2nd edn. Springer, Berlin

Körner C, Paulsen J (2004) A world-wide study of high altitude treeline temperatures. J Biogeogr 31:713-732

Korpel S (1995) Die Urwälder der Westkarpaten. Gustav Fischer, Stuttgart

Krumm F, Kulakowski D, Spiecker H, Duc P, Bebi P (2011) Stand development of Norway spruce dominated subalpine forests of the Swiss Alps. For Ecol Manag 262(4):620-628

Kuenstler G, Albert CH, Courbaud B, Lavergne S, Thuiller W, Vieilledent G, Zimmermann NE, Coomes DA (2011) Effects of competition on tree radial-growth vary in importance but not in intensity along climatic gradients. J Ecol 99(1):300-312

Kueppers LM, Southon J, Baer P, Harte J (2004) Dead wood biomass and turnover time, measured by radiocarbon, along a subalpine elevation gradient. Oecologia 141:641-651

Kulakowski D, Bebi P, Rixen C (2011) The interacting effects of land use change, climate change, and supression of disturbances on landscape forest structure in the Swiss Alps. Oikos 120:216-225

Leemans R (1991) Canopy gaps and establishment patterns of spruce (Picea abies (L.) Karst.) in two old-growth coniferous forests in Central Sweden. Vegetatio 93(2):157-165

Loehle C, LeBlanc D (1996) Model-based assessments of climate change effects on forests: a critical review. Ecol Model 90(1): $1-31$

Lyr H, Fiedler H-J, Tranquillini W (1992) Physiologie und Oekologie der Gehölze. Gustav Fischer, Jena

McCarthy JW, Weetman G (2006) Self-Thinning dynamics in a balsam fir insect mediated boreal forest chronosequence. For Ecol Manag 241:295-309
Monserud RA, Sterba H (1999) Modeling individual tree mortality for Austrian forest species. For Ecol Manag 113(2-3):109-123

Oberbauer SF, Billings WD (1981) Drought tolerance and water use by plants along an alpine topographic gradient. Oecologia 50(3):325-331

Oliver CD (1980) Forest development in North America following major disturbances. For Ecol Manag 3:153-168

Oliver CD, Larson BC (1996) Forest stand dynamics. Wiley, New York

Ott E (1978) Ueber die Abhängigkeit des Radialzuwachses und der Oberhöhen bei Fichte und Lärche von der Meereshöhe und Exposition im Lötschental. Schweizerische Zeitschrift für Forstwesen 3:169-193

Ott E, Lüscher F, Frehner M, Brang P (1991) Verjüngungsökologische Besonderheiten im Gebirgsfichtenwald im Vergleich zur Bergwaldstufe. Schweizerische Zeitschrift für Forstwesen 142(11):879-903

Ott E, Frehner M, Frey HU, Lüscher P (1997) Gebirgsnadelwälder: praxisorientierter Leitfaden für eine standortgerechte Waldbehandlung. Haupt, Bern; Stuttgart, Wien

Pecher C, Tasser E, Tappeiner U (2011) Definition of the potential treeline in the European Alps and its benefit for sustainability monitoring. Ecol Ind 11(2):438-447

Peet RK (2000) Forests and meadows of the Rocky Mountains. In: Barbour MG, Billings WD (eds) North American terrestrial vegetation, vol 2. Cambridge University press, Cambridge, pp 75-122

Peet RK, Christensen NL (1987) Competition and tree death. Bioscience 37(8):586-595

Platter FA, Sterba H (2008) The natural mortality of Norway spruce (Picea abies (L.) KARST), Scots pine (Pinus sylvestris L.) and European beech (Fagus sylvatica L.). In: Nagel J (ed) Jahrestagung der forstlichen. Sektion Ertragskunde, Trippstadt, p 179

Progar RA, Schowalter TD, Freitag CM, Morrell JJ (2000) Respiration from coarse woody debris as affected by moisture and saprotroph functional diversity in Western Oregon. Oecologia 124(3):426-431. doi:10.1007/pl00008868

Putallaz J-M (2011) Protection à long terme contre les avalanches surles surfaces de chablis Etude sur l'efficacité mécanique des arbres au sol. Masters Thesis, ETH Zürich, Zürich, Birmensdorf/ Davos

Rebetez M (2006) Mehr Trockenheit bei wärmeren Temperaturen? Trends von Temperatur- und Niederschlagsverhältnissen in der Schweiz. Forum für Wissen 2006:17-21

Rebetez M, Dupont O, Giroud M (2009) An analysis of the July 2006 heatwave extent in Europe compared to the record year of 2003. Theor Appl Climatol 95:1-7

Schmidtke H, Scherrer H-U (1997) Sturmschäden im Wald. NFP 31 Schlussbericht. ETH, Zürich

Schmidt-Vogt H (1987) Die Fichte, Band 1. Paul Parey, Hamburg und Berlin

Schönenberger W (2001) Cluster afforestation for creating diverse mountain forest structures-a review. For Ecol Manag 145(1-2):121-128

Spies TA, Franklin JF, Thomas TB (1988) Coarse woody debris in Douglas-fir forests of western Oregon and Washington. Ecology 69(6):1689-1702

Stevens V (1997) The ecological role of coarse woody debris: an overview of the ecological importance of CWD in B.C. forests., vol Work. Pap. 30/1997. Min. For., Victoria, BC

Stierlin H-R, Brändli U-B, Herold A, Zinggeler J (1994) Schweizerisches Landesforstinventar. Anleitung für die Feldaufnahmen der Erhebung 1993-1995. Eidg. Forschungsanstalt für Wald, Schnee und Landschaft WSL, Birmensdorf

Stokes MA, Smiley TL (1968) An introduction to tree ring dating. University of Chicago Press, Chicago 
Szwagrzyk J, Szewczyk J (2001) Tree mortality and effects of release from competition in an old-growth Fagus-Abies-Picea stand. J Veg Sci 12(5):621-626. doi:10.2307/3236901

Team RDC (2008) A language and environment for statistical computing. R Foundation for Statistical Computing. Vienna, Austria

Tranquillini W (1979) Physiological ecology of the alpine timberline: tree existence at high altitudes with special reference to the European Alps. Ecological studies, vol 31. Springer, Berlin

Vayssieres MP, Plant RE, Allen-Diaz BH (2000) Classification trees: an alternative non-parametric approach for predicting species distributions. J Veg Sci 11:679-694

Villalba R, Veblen T (1998) Influences of large-scale climatic variability on episodic tree mortality in Northern Patagonia. Ecology 79(8):2624-2640

Waring RH (1987) Characteristics of trees predisposed to die. Bioscience 37(8):569-574
Welden CC, Slauson LW (1986) The intensity of competition versus its importance: an overlooked distinction and some implications. Q Rev Biol 61(1):23-44

Wieser G, Tausz M (2007) Trees at their upper limit-treelife limitation at the alpine timberline, vol 5. Springer, Groningen

Wong CM, Lertzman K (2001) Errors in estimating tree age: implications for studies of stand dynamics. Can J For Res 31: 1262-1271

Zeileis A, Hothorn T, Hornik K (2005) Model-based recursive partitioning. Research Report Series/Department of Statistics and Mathematics, Vienna, p 19

Zielonka T (2006) When does dead wood turn into a substrate for spruce replacement? J Veg Sci 17(6):739-746. doi:10.1111/ j.1654-1103.2006.tb02497.x 